\title{
Evaluating botulinum toxin products for clinical use requires accurate, complete, and unbiased data
}

This article was published in the following Dove Press journal:

Clinical Ophthalmology

7 September 2011

Number of times this article has been viewed

\section{Andy Pickett \\ Toxin Science Limited, Wrexham, UK; Botulinum Research Center, UMASS \\ Dartmouth, MA, USA}

Correspondence: Andy Pickett Toxin Science Limited, Wrexham, LLI 2 8DU, UK

Tel +447921 164537

Email andy@toxinscience.com
Modern clinical use of botulinum toxin (BoNT) by doctors requires evidencebased facts and data to support their work. In particular, these need to be unbiased and complete. Too often in the past, speculative statements have been used and repeated until injectors have come to believe they are solid facts. ${ }^{1}$ Yet no supporting data exist. Consequently, doctors have often been reluctant to change to or even try other products because of what they have been told. This has not been a good situation for either clinicians or patients. We have published about these "urban legends"1 and tried, on many occasions, to correct these inaccuracies (see, for example,,$^{2,3}$ ).

Therefore the recent paper by Park and colleagues, claiming to be a review of a relatively new BoNT product used in blepharospasm, was disappointing at best. ${ }^{4}$ Many of the old and outdated claims about the properties of BoNT products have again been repeated. In 2011, this is an incorrect approach and borders on a marketing activity.

For example, the product data contained in their Table $1^{4}$ has no references cited as to the sources of information, is inaccurate, and does not even take into consideration previous publications which have highlighted errors in such tabular data. ${ }^{1}$ We published last year a definitive work on the formulation composition of BoNT products in clinical use ${ }^{5}$ specifically to stop these errors. We have previously suggested that authors contact manufacturers of BoNT products before they publish such data, to ensure complete accuracy; ${ }^{1}$ all of this has apparently been ignored by Park and colleagues.

Data in error in their Table 1 include the manufacturer of Myobloc $^{\circledR} /$ Neurobloc $^{\circledR}$ (this should be US WorldMeds, who acquired Solstice in August 2010), "stabilization" of Xeomin ${ }^{\circledR}$ (also a freeze-dried product and not as cited), the vial size of Dysport ${ }^{\circledR}$ (also available as 300 units per vial in many countries, including the United States), the vial sizes of Botox ${ }^{\circledR}$ (also available as a 50 and 200 units per vial product in many countries), the so-called "complex sizes" for each product (none of which exist for the BoNT-A products in the actual vial) ${ }^{6}$ and storage after reconstitution of Myobloc ${ }^{\circledR}$ (this is already liquid product and not stable "for a few hours" after reconstitution which simply does not happen!)

More important clinically, Park and colleagues have published a data line reporting "biological activity in relation to Botox ${ }^{\circledR}$ " in their Table $1,{ }^{4}$ citing a ratio of $1: 1$ for $\mathrm{Xeomin}^{\circledR}$ and 3:1 for Dysport. This so-called "dose equivalence ratio" is probably the 
Table I Clinical studies reported on the use of Xeomin ${ }^{\circledR}$ for the treatment of blepharospasm

\begin{tabular}{|c|c|c|c|}
\hline Authors & $\begin{array}{l}\text { Publication } \\
\text { year }\end{array}$ & $\begin{array}{l}\text { Patient number treated } \\
\text { with Xeomin }^{\circledR}\end{array}$ & Comments \\
\hline Roggenkamper et $\mathrm{al}^{23}$ & 2006 & 129 & First published use study \\
\hline Jankovic et $\mathrm{al}^{24}$ & 2009 & - & Poster - pre-report of 201 I study publication ${ }^{25}$ \\
\hline Jankovic et $\mathrm{al}^{26}$ & 2009 & - & Development of rating scale using earlier data ${ }^{23}$ \\
\hline Jankovic ${ }^{27}$ & 2009 & - & Review of earlier data ${ }^{23}$ \\
\hline Jankovic et $\mathrm{al}^{25}$ & 2011 & 75 & Second published use study \\
\hline Wabbels et $\mathrm{al}^{21}$ & 2011 & 33 & Third published use study \\
\hline
\end{tabular}

most contentious issue about use of BoNT-A products and should never be described so definitively. As the authors will know, the regulatory authorities around the world have required an insertion, in all BoNT-A product literature supplied to clinicians worldwide, which clearly states that the units of each product are specific to that product and are not interchangeable. In particular, many clinicians would strongly argue that any "ratio" between Dysport ${ }^{\circledR}$ and Botox ${ }^{\circledR}$ units is more likely to be 2 or 2.5:1, respectively, and not as cited in their table - different reviews of many data strongly indicate this.

Xeomin ${ }^{\circledR}$ is stated as "being obtained from the same strain of Clostridium botulinum as Botox ${ }^{\mathbb{B}}$. ${ }^{4}$ This is incorrect. The statement is contradicted by a publication which specifically looked at the subject ${ }^{7}$ and has been corrected in relation to another recent publication comparing BoNT-A products which reported the same error. ${ }^{8}$

One of the standard reasons always given why clinicians should use Xeomin ${ }^{\circledR}$ is the reduced potential to raise BoNT neutralizing antibodies in patients. This was, indeed, the prime reason for initially developing the product. ${ }^{9}$ Often, the subject of how the other proteins of the BoNT-A complex (the neurotoxin associated proteins - NAPs) may have immunostimulating properties has been raised (see, for example, $\left.{ }^{10}\right)$.However, this has never been demonstrated, even experimentally in animals. Park and colleagues have re-stated old data from flawed studies on this subject. ${ }^{11}$ They have, unfortunately, dismissed careful and critical appraisal of those studies by the leading expert in the field of BoNT immunology, Professor Zouhair Atassi. ${ }^{10,12}$

There is currently no evidence that the removal of the BoNT-A NAPs from Xeomin ${ }^{\circledR}$ has had any beneficial effects on reducing BoNT-A neutralizing antibody formation in patients. The current immunological status for the product is carefully described in the current United States prescribing information for Xeomin ${ }^{\circledR}$ - "the potential for antibody formation has not been fully characterized". ${ }^{13}$ Statements such as "may reduce the risk markedly"4 are inappropriate in the context of critically reviewing and assessing the properties of a BoNT-A product for clinical use.

Indeed, Park and colleagues have cited a 17-year-old reference that describes the levels of antibody formation in patients treated with BoNT-A. ${ }^{14}$ These data originated from use of "old" Botox ${ }^{\circledR}$, that is the original version of Botox $^{\circledR}$ pre-1997, which was known to contain significant levels of inactive BoNT. ${ }^{15}$ The inactive BoNT promoted neutralizing antibody responses in patients treated with high doses for conditions such as cervical dystonia, according to the treatment regimens in use at that time (typically, short intervals between injections, "booster" injections, when effects were not apparent after short periods). For modern clinical data dealing with blepharospasm, the report of Bentivoglio and colleagues ${ }^{16}$ on a large group of patients treated long term with BoNT reported only three patients $(2.3 \%)$ who likely had antibodies (but also not determined by direct assay).

Indeed, one animal study which apparently found that Xeomin ${ }^{\circledR}$ raised no neutralizing antibodies under conditions where other BoNT-A products did, has been cited by Park and colleagues, namely that of Blumel et al reported actually in 2005. ${ }^{17}$ Unfortunately this was a poster at an international conference. Careful assessment of those data showed that the doses used of one product in the comparison were so high that they killed several of the test animals. The study was invalidated for comparative purposes.

One factor of product comparison that Park and colleagues $^{4}$ have used is the amount of BoNT protein that would be injected for each product as used in therapy. This is designated the "protein load" of the product, presented as nanograms (ng) per vial. ${ }^{18}$ The basis of their argument is that injecting patients with less BoNT protein per treatment is a way of reducing the risk of antibody response. However, they have repeated, yet again, incorrect data for Dysport $^{\mathbb{R}}$. We have published several times over the last 8 years clearly describing the Dysport ${ }^{\circledR}$ historic data for protein load over a 15 -year period..$^{18}$ No similar data have 
ever been published for the other BoNT-A products. The correct figure is $4.35 \mathrm{ng}$ of Dysport ${ }^{\circledR}$ per vial, not $12.5 \mathrm{ng}$ as Park and colleagues have cited - from a reference related to $\mathrm{Xeomin}^{\circledR}$ ! $^{10}$

But, strangely, Park et $\mathrm{al}^{4}$ have not used and compared data on the Xeomin ${ }^{\circledR}$ protein load per vial that have recently been published. ${ }^{19}$ These new data, giving 0.44 ng per vial, significantly contradict those previously reported for Xeomin ${ }^{\circledR}$ of $0.6 \mathrm{ng}$ per vial. ${ }^{10}$ True, these are very small amounts but they actually represent a significant difference as reported by the product manufacturer. These differences have recently been challenged ${ }^{8}$ but no satisfactory explanation has been provided in response. ${ }^{20}$ Which figure is correct? What is the long-term consistency of the product?

Park et al have discussed the clinical data available for the use of Xeomin ${ }^{\circledR}$ in blepharospasm. In fact, to my knowledge only six clinical papers on treatment of this condition with the product are listed in PubMed. Of these, one is a poster abstract, two repeat or re-analyze data from a previous study, leaving only three studies overall (Table 1). The study by Wabbels and co-workers ${ }^{21}$ was not referenced by Park et al, ${ }^{4}$ leaving only two studies with which to conduct their review. Over all studies, just 237 patients are reported in the literature as treated with the product since first licensure in 2005 (Table 1). Park et $\mathrm{al}^{4}$ have also included in their review use of the product in other conditions such as cervical dystonia. Given that cervical dystonia is a large-muscle condition which requires large doses of BoNT-A for efficacy, certainly in comparison with blepharospasm, the dissimilarity between the conditions seems to outweigh the use of the different data sets for the review of use in blepharospasm. Facial muscles, as treated in blepharospasm, have a fundamentally different distribution of BoNT target neuromuscular junctions compared with larger muscles of the body. ${ }^{22}$

The reader must make up their own mind as to whether the review appropriately deals with the subject in question. But issues, especially with accuracy of data cited, must also be taken into proper account.

\section{Disclosure}

The author declares no conflicts of interest.

\section{References}

1. Pickett A, Caird D. Comparison of type a botulinum toxin products in clinical use. J Clin Pharm Ther. 2008;33(3):327-328.

2. Pickett A, Dodd S, Rzany B. Confusion about diffusion and the art of misinterpreting data when comparing different botulinum toxins used in aesthetic applications. J Cosmet Laser Ther. 2008;10(3): 181-183.
3. Pickett A. Dysport ${ }^{\mathbb{E}}$ : Pharmacological properties and factors that influence toxin action. Toxicon. 2009;54(5):683-689.

4. Park J, Lee MS, Harrison AR. Profile of Xeomin ${ }^{\circledR}$ (incobotulinumtoxinA) for the treatment of blepharospasm. Clin Ophthalmol. 2011;5: 725-732.

5. Pickett A, Perrow K. Formulation composition of botulinum toxins in clinical use. J Drugs Dermatol. 2010;9(9):1085-1091.

6. Eisele K-H, Fink K, Vey M, Taylor HV. Studies on the dissociation of botulinum neurotoxin type A complexes. Toxicon. 2011;57(4): 555-565.

7. Fang P-K, Raphael B, Maslanka S, Cai S, Singh B. Analysis of genomic differences among Clostridium botulinum type A1 strains. $B M C$ Genomics. 2010;11(1):725.

8. Pickett A. Consistent Biochemical data are essential for comparability of botulinum toxin type A products. Drugs R D. 2011;11(1):97-98.

9. Dressler D. Routine use of Xeomin ${ }^{\circledR}$ in patients previously treated with Botox: long term results. Eur J Neurol. 2009;16 Suppl 2:2-5.

10. Frevert J. Xeomin ${ }^{\circledR}$ is free from complexing proteins. Toxicon. 2009; 54(5):697-701.

11. Lee JC, Yokota K, Arimitsu H, et al. Production of anti-neurotoxin antibody is enhanced by two subcomponents, HA1 and HA3b, of Clostridium botulinum type B $16 \mathrm{~S}$ toxin-haemagglutinin. Microbiology. 2005;151(Pt 11):3739-3747.

12. Atassi MZ. On the enhancement of anti-neurotoxin antibody production by subcomponents HA1 and HA3b of Clostridium botulinum type B 16S toxin-haemagglutinin. Microbiology. 2006;152(Pt 7): 1891-1895.

13. Xeomin ${ }^{\circledR}$ prescribing information http://www.accessdata.fda.gov/ drugsatfda_docs/label/2010/125360lbl.pdf. Accessed July 19, 2011.

14. Greene P, Fahn S, Diamond B. Development of resistance to botulinum toxin type A in patients with torticollis. Mov Disord. 1994; 9(2):213-217.

15. Borodic G, Johnson E, Goodnough M, Schantz E. Botulinum toxin therapy, immunologic resistance, and problems with available materials. Neurology. 1996;46(1):26-29.

16. Bentivoglio AR, Fasano A, Ialongo T, Soleti F, Lo FS, Albanese A. Fifteen-year experience in treating blepharospasm with Botox or Dysport: same toxin, two drugs. Neurotox Res. 2009;15(3):224-231.

17. Blumel J, Frevert J, Schwaier A. Comparative antigenicity of three preparations of botulinum neurotoxin type A in the rabbit. Paper presented at: 5 th Triennial International Conference on Basic and Therapeutic Aspects of Botulinum and Tetanus Toxins (Toxins 2005) 2005; Denver, Colorado, USA.

18. Panjwani N, O'Keeffe R, Pickett AM. Biochemical, functional and potency characteristics of type A botulinum toxin in clinical use. The Botulinum Journal. 2008;1(1):153-166.

19. Frevert J. Content of botulinum neurotoxin in Botox ${ }^{\circledR} / V$ istabel ${ }^{\circledR}$, Dysport $^{\circledR} /$ Azzalure $^{\circledR}$, and $\mathrm{Xeomin}^{\circledR} /$ Bocouture $^{\circledR}$. Drugs R D. 2010; 10(2):67-73.

20. Frevert J. Author's Reply. Drugs R D. 2011;11(1):98-99.

21. Wabbels B, Reichel G, Fulford-Smith A, Wright N, Roggenkamper P. Double-blind, randomised, parallel group pilot study comparing two botulinum toxin type A products for the treatment of blepharospasm. J Neural Transm. 2011;118(2):233-239.

22. Happak W, Liu J, Burggasser G, Flowers A, Gruber H, Freilinger G. Human facial muscles: dimensions, motor endplate distribution, and presence of muscle fibers with multiple motor endplates. Anat Rec. 1997;249(2):276-284.

23. Roggenkamper P, Jost WH, Bihari K, Comes G, Grafe S. Efficacy and safety of a new Botulinum Toxin Type A free of complexing proteins in the treatment of blepharospasm. $J$ Neural Transm. 2006;113(3): 303-312.

24. Jankovic J, Comella C, Hanschmann A, Grafe S. Efficacy and safety of NT 201 (botulinum neurotoxin free from complexing proteins) in blepharospasm. Paper presented at: American Academy of Neurology 61st Annual Meeting 2009; Seattle, WA. 
25. Jankovic J, Comella C, Hanschmann A, Grafe S. Efficacy and safety of incobotulinumtoxinA (NT 201, Xeomin ${ }^{\circledR}$ ) in the treatment of blepharospasm - a randomized trial. Mov Disord. 2011;26(8): $1521-1528$.

26. Jankovic J, Kenney C, Grafe S, Goertelmeyer R, Comes G. Relationship between various clinical outcome assessments in patients with blepharospasm. Mov Disord. 2009;24(3):407-413.
27. Jankovic J. Clinical efficacy and tolerability of Xeomin ${ }^{\circledR}$ in the treatment of blepharospasm. Eur J Neurol. 2009;16:14-18.

\section{Publish your work in this journal}

Clinical Ophthalmology is an international, peer-reviewed journal covering all subspecialties within ophthalmology. Key topics include: Optometry; Visual science; Pharmacology and drug therapy in eye diseases; Basic Sciences; Primary and Secondary eye care; Patient Safety and Quality of Care Improvements. This journal is indexed on
PubMed Central and CAS, and is the official journal of The Society of Clinical Ophthalmology (SCO). The manuscript management system is completely online and includes a very quick and fair peer-review system, which is all easy to use. Visit http://www.dovepress.com/ testimonials.php to read real quotes from published authors. 